\title{
A Review of the Application and Performance of Carbon Nanotubes in Fuel Cells
}

\author{
Chong Luo, Hui Xie, Qin Wang, Geng Luo, and Chao Liu \\ Key Laboratory of Low-Grade Energy Utilization Technologies and Systems of Ministry of Education, \\ College of Power Engineering, Chongqing University, Chongqing 400030, China \\ Correspondence should be addressed to Hui Xie; xiehui@cqu.edu.cn
}

Received 25 September 2014; Revised 17 April 2015; Accepted 20 April 2015

Academic Editor: Myoung-Woon Moon

Copyright (C) 2015 Chong Luo et al. This is an open access article distributed under the Creative Commons Attribution License, which permits unrestricted use, distribution, and reproduction in any medium, provided the original work is properly cited.

\begin{abstract}
The fuel cell has the nature of high energy conversion efficiency and low pollutant emission. Carbon nanotubes used for fuel cells can decrease the needs of noble metals which are used for catalyst and improve the performance of fuel cells. The application of carbon nanotubes in fuel cells is summarized and discussed. The following aspects are described in this paper: the method used to reduce the platinum, the effect of carbon nanotubes on the fuel cell, improving the performance of fuel cell catalysts, the interaction between catalyst and carbon nanotube support, and the synthetic conditions of carbon nanotube supported catalyst. We summarize some of the results of previous studies and raise expectations for the microscopic state study of carbon nanotubes in the future.
\end{abstract}

\section{Introduction}

The fuel cell is a device which directly converts chemical energy into electrical energy. It has high energy conversion efficiency and low emissions [1-3]. Fuel cells are considered to be one of the promising methods to solve future energy crisis and environmental issues.

In recent years, in order to improve the efficiency of the fuel cell, a lot of studies are carried out from different ways.

In order to improve the efficiency of the fuel cell, the catalyst is needed. The noble metal Pt has the good catalytic efficiency. However, Pt is expensive, which is a huge obstacle for fuel cell to be commercialized $[2,3]$. So we need to reduce the use of $\mathrm{Pt}$ and develop new catalysts improving the oxidation-reduction reaction (ORR) of the electrode [4].

The support of catalyst can help improve the capability of catalyst $[5,6]$. Common catalysts support includes carbon, graphene, carbon nanotube (CNT), and other forms of carbon. Low content of platinum catalyst being thin film layer has been reported to be effective and provides a higher quality of Pt utilization and activity $[7,8]$. Graphene nanosheet as an ideal alternative compared with the traditional carbon support materials has a high electrical activity of the catalyst and superior durability than the commercial $\mathrm{Pt} / \mathrm{C}$ catalyst [9]. Furthermore, the support of iron-based catalyst is porous carbon used in polymer electrolyte fuel cell, which can improve the fuel cell oxygen reducing ability. So the supports are really important for fuel cells. CNT as a support can effectively improve the catalyst performance and utilization [10]. Nowadays, the CNTs adopted in fuel cells are receiving wide attention.

This paper focuses on describing the study about the performance of CNTs and the latest advances in fuel cell applications.

\section{CNT Used to Reduce the Using of Platinum}

In order to reduce the amount of platinum and make sure the activity and stability of the catalyst at a high level, the following methods are mainly used. There is an example of proton exchange membrane fuel cell in Figure 1 [3], so that we can have a better understanding of fuel cell.

2.1. Using the Support to Reduce the Use of Pt. Jha et al. used proton exchange membrane fuel cell (PEMFC) structure to base on functionalized single-walled CNTs (SWCNT), making the Pt loading to reach $0.06 \mathrm{mg} \mathrm{Pt} / \mathrm{m}^{2}$, far below the $0.125 \mathrm{mg} \mathrm{Pt} / \mathrm{m}^{2}$ - the United States Department of Energy 2017 loading of technical indicators about platinum group 


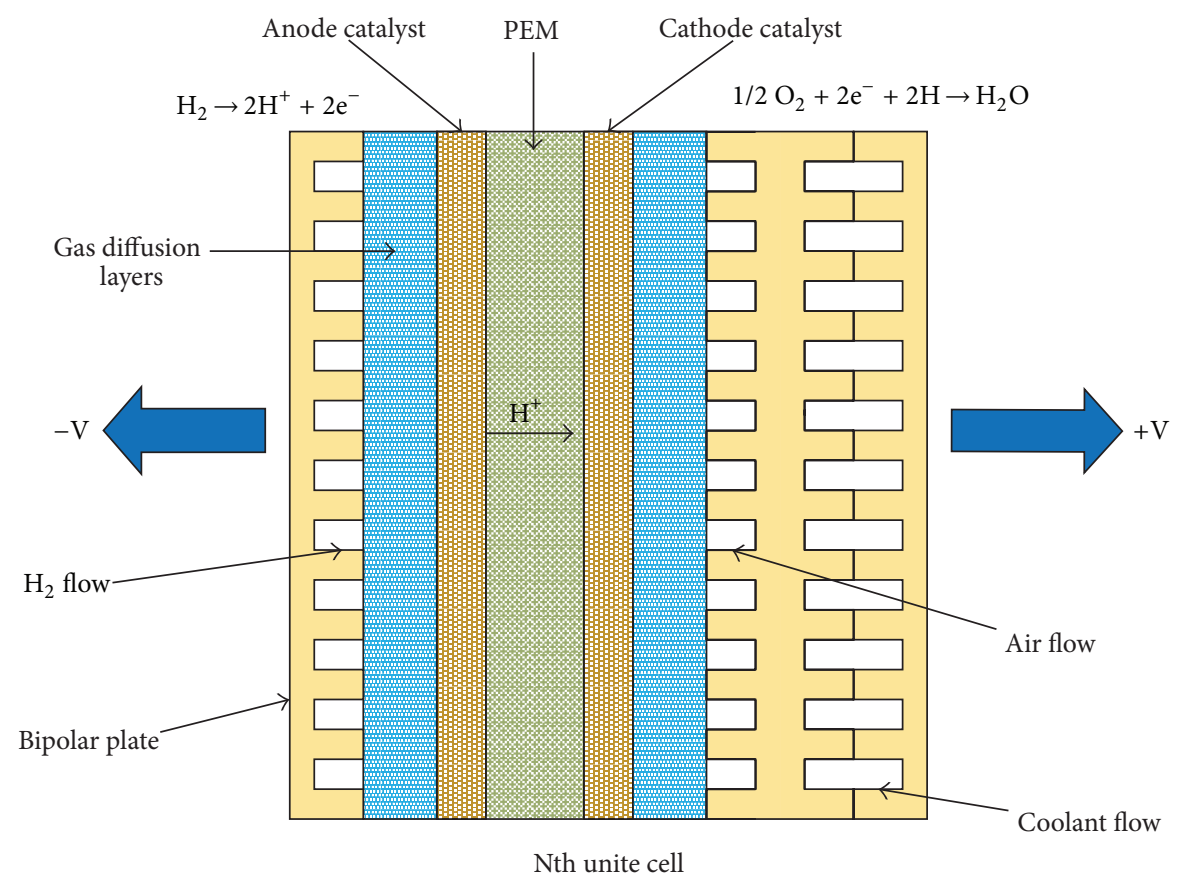

FIGURE 1: Fuel-cell components [3].

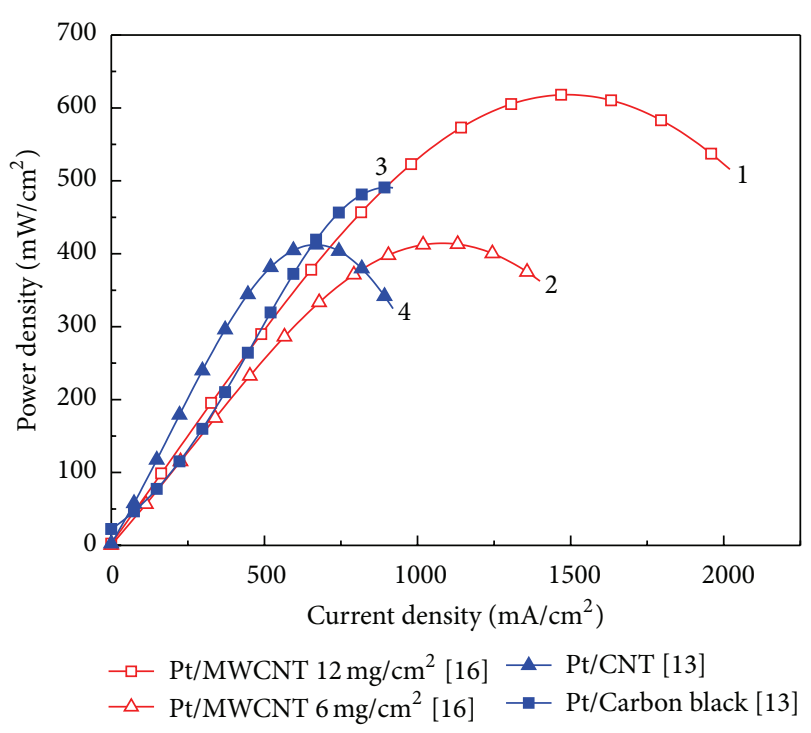

FIGURE 2: Current density based fuel cell performance curves.

metals (PGM) [11]. Girishkumar et al. found that the CNT as support for fuel cells rather than the support of carbon black for the Pt catalyst has a better catalyst activity and a higher current density [12]. Therefore, CNT can effectively reduce the use of $\mathrm{Pt}[13,14]$. So CNTs that are used as support can effectively improve the performance of the catalysts $[15,16]$.

In Figure 2, curves 1 and 2 are two catalysts in Hydrogen Fuel Cells. Pt/multiwalled CNTs (MWCNT) $\left(12 \mu \mathrm{g} / \mathrm{cm}^{2}\right)$ have a better power density [16]. As a result, in the same condition, having a higher Pt loading will get a better power density. Curves 3 and 4 are the performance of the Pt/Carbon Black and Pt/CNT [13]. When the current is not too high, the power density of Pt/CNT electrode is much higher. In a word, we can get the different current density when we use different fuel cell, as their conversion efficiency is different. Therefore, the use of catalyst support has an important significance in the fuel cell applications.

2.2. Exploring Pt-Containing Alloys as a Catalyst. Catalysts composed by CNT as the support of Pt-Ru alloy have good dispersion and catalytic [17-19]. By comparing the Pt/MWCNTs, PtNi/MWCNTs, and PtRu/MWCNTs electrodes, the studies found PtRuNi/MWCNTs have better electrocatalytic activity [20]. When Au-CNT is used, phosphate buffer solution, isopropanol, and Nafion membrane can be mixed separately getting PdPtPt/Au-CNT, PtPdPd/Au-CNT, and $\mathrm{PtPdPt} / \mathrm{Au}-\mathrm{CNT}$ catalysts by the way of continuous precipitation. These catalysts are suitable for different environments and have good catalytic effect [21].

Just as the research of Wu et al., Pt-containing alloy as catalyst has a better performance than the commercial $\mathrm{Pt} / \mathrm{C}$ catalyst in Figure 3 [22]. Besides, three $\mathrm{Pt}_{3} \mathrm{Ni}$ catalysts were more active than Pt. In this case, the alloy using as catalysts can be a good substitute for fuel cells.

In a word, it can be concluded that it is effective to improve catalysis performance by using Pt alloy or other metal alloys with CNT support [22-30]. In addition, it should be noted that the compound temperature of the alloy will effect the catalytic activity with the heat treatment [31].

2.3. No Pt-Containing Catalysts. In order to reduce the use of $\mathrm{Pt}$, researchers attempt to use cheaper alternatives to achieve the same effect. Sheng et al. found that multiwalled CNTs as the support of $\mathrm{Cu} / \mathrm{Cu}_{x} \mathrm{O}$ rather than $\mathrm{Pt}$ nanoparticles 


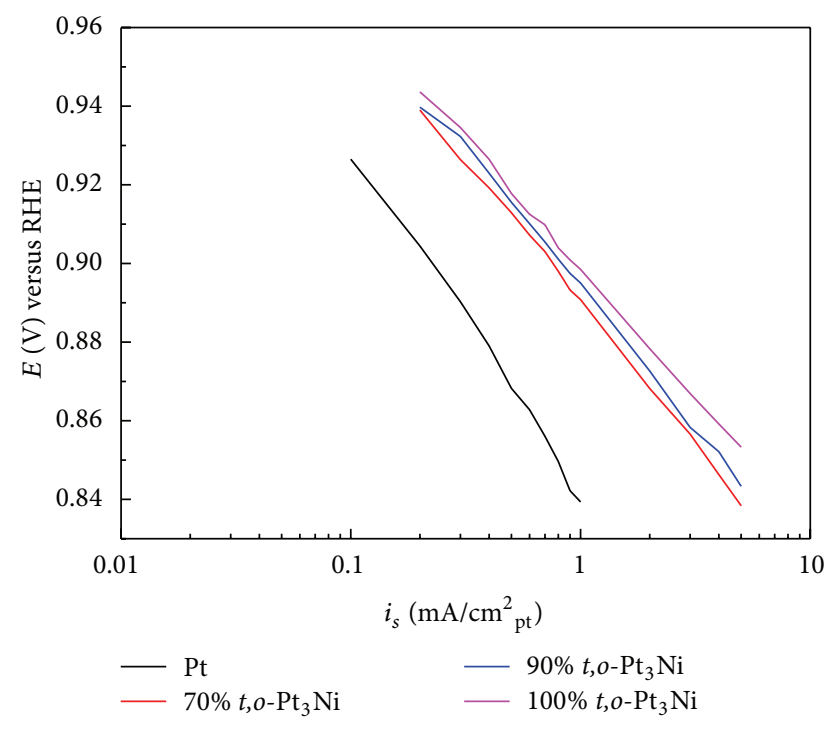

FIGURE 3: The performance of catalysts [22].

have higher catalytic activity [32]. Wang et al. found when polyelectrolyte functionalized carbon nanotubes can comprise the metal-free catalyst and are used to the oxidationreduction reaction, it has a similar property to $\mathrm{Pt}$ catalyst in a fuel cell [33]. When PtRu/MWCNT and PtSn/MWCNT as anode catalyst, respectively, nonprecious cobalt-polypyrrole MWCNTs have the improved power density than no Pt based electrocatalysts as the cathode [34]. The electrode with $\mathrm{Mo}_{2} \mathrm{C}$ catalyst using the support of CNTs has a higher overvoltage than Pt-based electrode, and its activity may be further improved [35]. The nanocomposite of multiwalled CNTs and $\mathrm{SnO}_{2}$, constituting the anodes of microbial fuel cells in the electrode, has a larger maximum power density; therefore the nanocomposite of multiwalled CNTs and $\mathrm{SnO}_{2}$ is a very desirable anode material [36]. The electrocatalytic activity of CNTs as the support of $\mathrm{Mo}_{2} \mathrm{C}$ (16.7 wt.\% Mo) catalyst is equivalent to the Pt catalyst (20 wt.\%) [37]. What is more, the catalyst is formed with $\mathrm{Pd}_{x} \mathrm{Co}$-two metal alloy and multiwalled CNTs, which has the better activity. Moreover, $\mathrm{Pd}_{3} \mathrm{Co} / \mathrm{MWCNT}\left(2.53 \mathrm{~mW} / \mathrm{cm}^{2}\right)$ has a better catalytic performance than Pd/MWCNT $\left(1.64 \mathrm{~mW} / \mathrm{cm}^{2}\right)$ and $\mathrm{Pt} / \mathrm{C}$ $\left(1.20 \mathrm{~mW} / \mathrm{cm}^{2}\right)$ as the cathode applied in the fuel cell [38]. As is reported in the thesis of Lefèvre et al. [39], the current density of a cathode made with the best iron-based electrocatalyst can equal that of platinum-based cathode.

Therefore, compared to the platinum-containing catalyst, nonnoble metal catalysts with the CNT support for the electrode also have good catalytic effectivity $[40,41]$ and stability [42].

2.4. Using of Pt Nanoparticles. Ru-decorated Pt nanoparticles on Nitrogen-doped multiwalled CNTs used for directly methanol fuel cells have high performance and high dispersion [43]. On the one hand, the polymer composition of Pt nanoparticles loaded into the MWCNT shows higher electrocatalytic activity and better tolerance as the anode of direct methanol fuel cell [44]. On the other hand, the shape and surface's morphology of CNTs has a profound impact on its electrocatalytic activity. When attached to the Pt nanoparticles, the electrical properties of flower-shaped nanostructure are significantly higher than conventional electro-catalytic properties of spherical nanoparticles [45].

So the use of Pt nanoparticles can well reflect the performance of the catalyst [46, 47], and Pt nanoparticles can be more dispersed on the surface of the support, thereby improving the utilization rate of platinum.

\section{Effect of CNTs on Fuel Cell}

Among the supports, CNT has a high surface area and high electrical conductivity, light weight, perfect hexagonal structure and many unusual mechanical, and electrical and chemical properties. In a silicon microfuel cell test, the $\mathrm{PtRu}$ graphitic carbon nanofibers, PtRu CNTs, and PtRu-Vulcan catalysts were used. The results obtained have shown that $\mathrm{PtRu}$ nanotubes have a maximum power density; PtRuVulcan has maximum durability [48]. Therefore CNTs are better able to improve the activity and get widespread attention. CNTs can improve the fuel cell performance, mainly in the following areas.

3.1. Improving the Performance of the Catalyst. The use of CNTs improves the performance of catalyst $[49,50]$. Platinum can be fixed in the inner wall and the outer wall of CNTs and may constitute platinum-CNTs having good electrocatalytic properties [51]. The fuel cell using CNTs as a catalyst support has a larger current density [52]. And the fuel cell has a high performance, catalytic activity and the quality of transmission $[53,54]$. In proton exchange membrane fuel cell, the surface of the bipolar plate is covered by conductive polymer coating (aluminum-coated). Adding the CNTs to polyaniline coating can enhance the conductive properties of the polyaniline polymer [55].

Therefore, while CNTs are of the catalyst support, the electrocatalytic properties of catalyst can be improved $[52,56$, 57].

3.2. Improving the Stability and Corrosion Resistance of the Catalyst. CNTs can make the fuel cell more stable [58] and have higher corrosion resistance performance in work. CNT as catalyst support for fuel cells can reduce the formation of surface oxides and corrosion current as is shown in Figure 4 [59].

From Figure 4, Pt supported on MWCNT and Vulcan XC-72 has similar initial half wave potential. With time going on, MWCNT exhibits a much slower decrease rate than Vulcan XC-72 of the half wave potential [59].

Studies have shown that, in the fuel cell, the CNT as catalyst support is more stable than the carbon black XC-72, is more resistant to corrosion, and has a higher peak power density $[50,60]$. The oxidized graphene catalyst supported on CNTs is coated on the melamine sponges as electrode prepared by the special method. And it can prove a large 


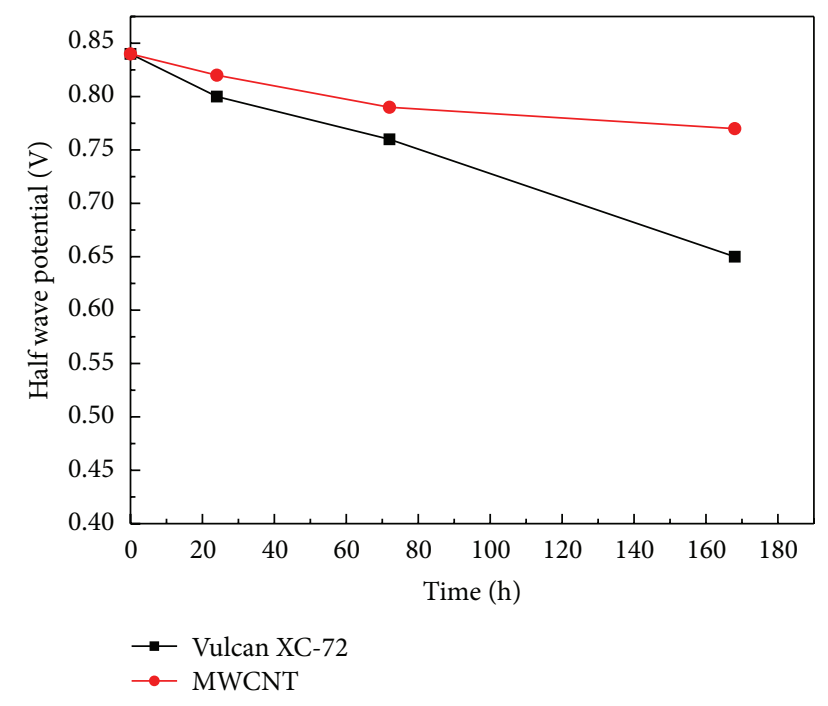

FIgure 4: Comparison of half potential for ORR between $\mathrm{Pt}$ supported on Vulcan XC-72 and MWCNT as a function of oxidation treatment time.

conductive surface of microbial fuel cell for transferring electrons; compared to the conventional carbon-based anode and the metal group, it can have better durability and catalytic activity [61].

3.3. Reducing the Cost of the Fuel Cell. The CNT has a high surface area, good support for $\mathrm{Pt}$, and high dispersion of the platinum, getting a smaller particle size [62]. So it can reduce the cost of production by reducing the use of platinum [63, 64].

\subsection{Increasing Transmission Capacity}

(1) Electron transport capabilities: CNTs as electrode in solid acid fuel cell can improve the connection between platinum catalyst nanoparticles and current collector [65]. And multiwalled CNTs increase the anode surface area and the volume ratio, enhancing the ability of the anode electron transmission in microbial fuel cells [66].

(2) Quality of transmission capacity: The mixture of multiwalled CNTs and single-walled CNTs used as Pt support can enhance the cathode quality activities and the mass transport in the catalyst layer, which can be a good method to ameliorate the mass transfer, when SWNT is used as catalyst support [67].

\section{Improving the Performance of Catalysts by Using CNT}

\subsection{Optimization of Support}

4.1.1. Nitrogen-Containing Catalyst Support. It can effectively improve the catalytic activity and stability, introducing the nitrogen functional group on the carbon support for

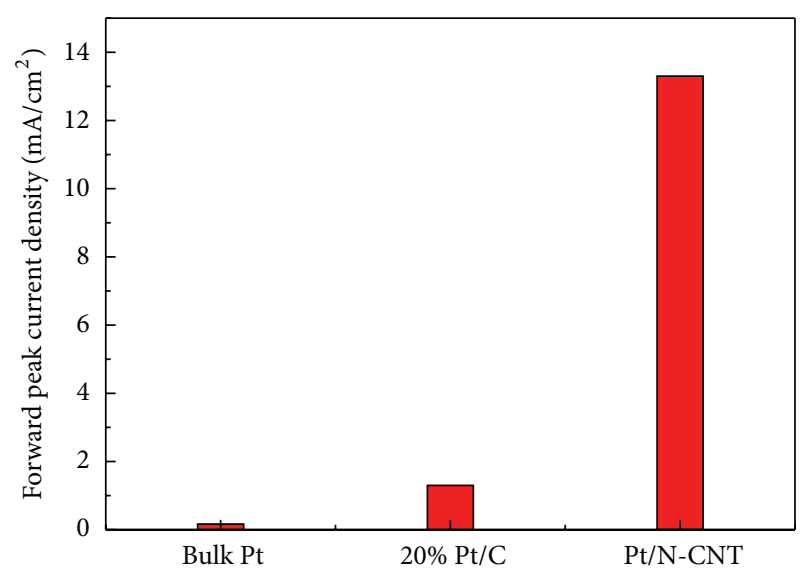

FIGURE 5: Peak current density for methanol oxidation on the various electrodes.

the catalyst [68-70]. Cheng et al. found PtRu nanoparticles are supported onto poly(diallyldimethylammonium chloride) (PDDA), polyethylenimine (PEI), 1-aminopyrene (AP), and tetrahydrofuran (THF) functionalized multiwalled CNTs. Pt-Ru nanoparticles supported on PEI, AP, and PDDA functionalized CNTs exhibited significantly much higher electrocatalytic activity and stability for the electro-oxidation of methanol as compared with PtRu supported on THFCNTs [71]. Platinum supported on multiwalled CNTs doped with nitrogen, as the cathode catalyst, has a higher maximum power density $\left(0.78 \mathrm{~mW} / \mathrm{cm}^{2}\right)$ than commercial carbon supported Pt catalyst $\left(0.72 \mathrm{~mW} / \mathrm{cm}^{2}\right)$. When the oxidant is the actual gas, the use of the former has a significantly higher performance in direct methanol fuel cell [72]. Maiyalagan et al. [69] have done the experiment for nitrogen-containing catalyst support in Figure 5, which could testify the advantage of nitrogen-containing CNT.

\subsubsection{Other Forms of Carbon Added}

(1) The fuel cell supported by the mixed electrode material of Graphene and multiwalled CNTs has a good catalytic effect [73]. Pham et al. got the unique layered graphene-CNT hybrid structures by a chemical vapor deposition method. Then they used the structures to support the Pt catalyst and found the catalyst for a fuel cell had superior polarization performance [74]. Therefore, adding graphene into the support can effectively improve the catalytic performance.

(2) Carbon shells embedded carbon nanotubes can facilitate Pt nanoparticles dispersing on the core-shell nanostructural support and the carbon shell embedded carbon nanotube supported Pt catalyst will form a new catalyst, and this catalyst has a higher electrochemical activity surface area and mass activity than the Pt catalyst loading on the original CNTs [75].

(3) CNTs and oxidized graphite form a three-dimensional carbon fiber composited material, just as 
a sandwich, which gives a maximum PEMFC performance of $495 \mathrm{~mW} / \mathrm{cm}^{2}$ at $60^{\circ} \mathrm{C}$ temperature [76].

4.1.3. Adding Substances to CNT to Synthetize the Support. Adding new substances on the CNTs synthetizes new support to improve its performance; the researchers made a lot of attempts and exploration. Examples are listed below:

(1) Sulfonated polyamide (PA-S) and sulfonation of polystyrene (PS-S) are two categories of mechanically robust and thermally stable nanocomposites, respectively, based on multiwalled CNT and silica nanotube (SiNT). Through solution blending, they were well dispersed and adhered on the nanostructures, forming a porous membrane structure for a fuel cell, which has high proton conductivity of $1.28-2.23 \mathrm{~S} / \mathrm{cm}$ at $80^{\circ} \mathrm{C}$ and higher water retention capacity [77].

(2) CNT is doped with heteroatoms forming a coresheath nanostructure, which is attached to the CNTs forming the catalyst. Compared to $\mathrm{Pt} / \mathrm{C}$ catalyst, it has higher durability. When used as the cathode catalyst, it exhibits very high current and power density [78].

(3) The composed film using CNTs and polytetrafluoroethylene is located between the bipolar plate and the electrode. The contact resistance is reduced. Therefore, the proton-exchange membrane fuel cell output power is increased by about 1.6 times [79].

4.1.4. Surface Treatment of CNTs. Some substances were coated on the surface of CNTs to improve performance. The following examples show part of the studies:

(1) By coating mesoporous polysulfone substrate on SWNTs forming a three-dimensional porous polysulfone-SWCNT, which is used as an anode in a microbial fuel cell, it has a high activity of surface region and the effective electron transfer in outer cells [80].

(2) The surfactant was adsorbed on the surface of functionalized MWCNTs, where they prevented reaggregation of MWCNTs on the nanocomposite. Thereby enhancing the dispersion of nanocomposite materials, the prepared CNTs used in proton exchange membrane can enhance the thermal performance [81].

4.2. Multimetal Addition of the Catalyst. Studies have shown that the multiwalled CNTs are used as the support with $\mathrm{Pd}$ catalyst in anode, respectively, and $\mathrm{Rh}, \mathrm{Ru}, \mathrm{Pt}, \mathrm{Au}, \mathrm{Ag}, \mathrm{Pd}, \mathrm{Ni}$, and $\mathrm{Cu}$ as the cathode catalyst for direct reduction of $\mathrm{H}_{2} \mathrm{O}_{2}$. The fuel cell maximum power density in descending order is $\mathrm{Au}>\mathrm{Ru}>\mathrm{Pt}>\mathrm{Ag}>\mathrm{Rh}>\mathrm{Pd}>\mathrm{Ni}>\mathrm{Cu}[82]$. Therefore, the use of various metals may have an impact on the catalytic activity [83]; we have a need to study the impact of the performance of various metals adding to the catalyst.

For example, Ni added to PtRu catalyst with the support of multiwalled CNTs can improve the electrochemical surface of the catalyst; meanwhile, comparing with the commercial

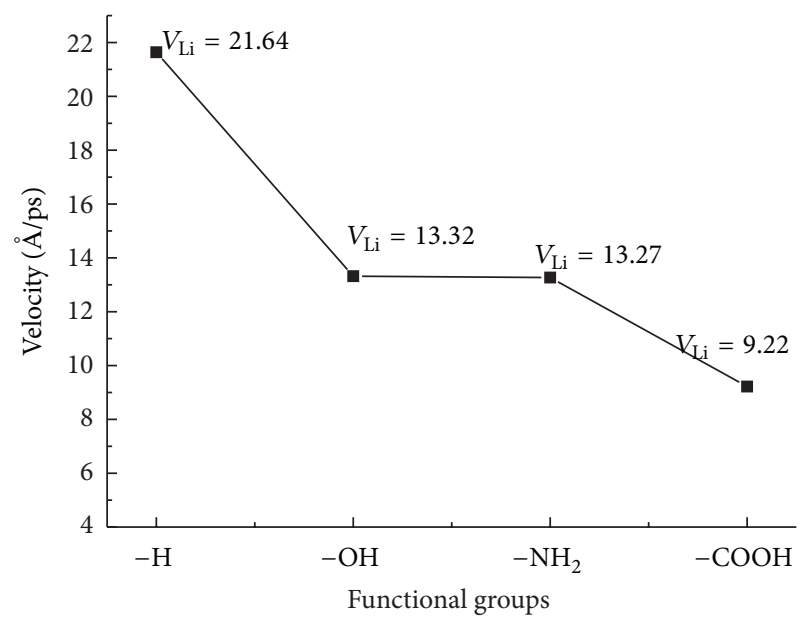

FIGURE 6: Effects of functional groups.

catalyst (20 wt.\% PtRu/C), it has an effect in which the PtRu loading is reduced (10 wt.\% PtRu) and a similar catalytic effect can be achieved [84]. Using CMK-3, ferrocene nickel as nickel source will be allowed to grow on CNTs, by chemical vapor deposition method. Through traditional wet impregnation method, we can get Pt catalyst. As a result, Pt particles get smaller, and they have a better performance under the conditions of a smaller Pt loading [85].

4.3. Using Oriented CNTs. Pt is supported on the oriented CNTs. In this way they form the catalyst, which has a good durability and reduces the loading amount of Pt; thereby we reduced the manufacturing costs. Using it in proton exchange membrane, fuel cell can have a higher energy density and current density [86]. Studies have shown that the oriented CNT film as cathode of the proton exchange membrane fuel cell can achieve a higher performance and a higher electrocatalytic activity than the disorder CNT membrane system of Pt/CNT [53]. Vertically aligned CNTs together with Pt forming the electrodes can be a good transfer of protons, electrons, and water. Catalyst layer and microporous layer have a good conduction for proton exchange membrane fuel cell, resulting in very good current density and reducing the use of Pt [87].

4.4. Functionalization of CNTs. While the port of CNT is functionalized, MWCNT-OH has a better power density than MWCNT-COOH [88]. The molecular dynamics simulation results also show that the functional groups on the port of the CNTs have a significant influence on the mass transporting through the port. As shown in Figure 6 [89], the speed of lithium-ion getting into the functionalized CNTs' port with hydroxy $(-\mathrm{OH})$ is faster than with carboxyl $(-\mathrm{COOH})$.

4.5. The Use of Polymers. Filling polyethylene terephthalate (PET) and polyvinylidene fluoride (PVDF) into CNTs, we can form a triple continuous structure. It can be applied to a proton exchange membrane fuel cell's bipolar plate, with excellent conductivity and strength [90]. Film, based 


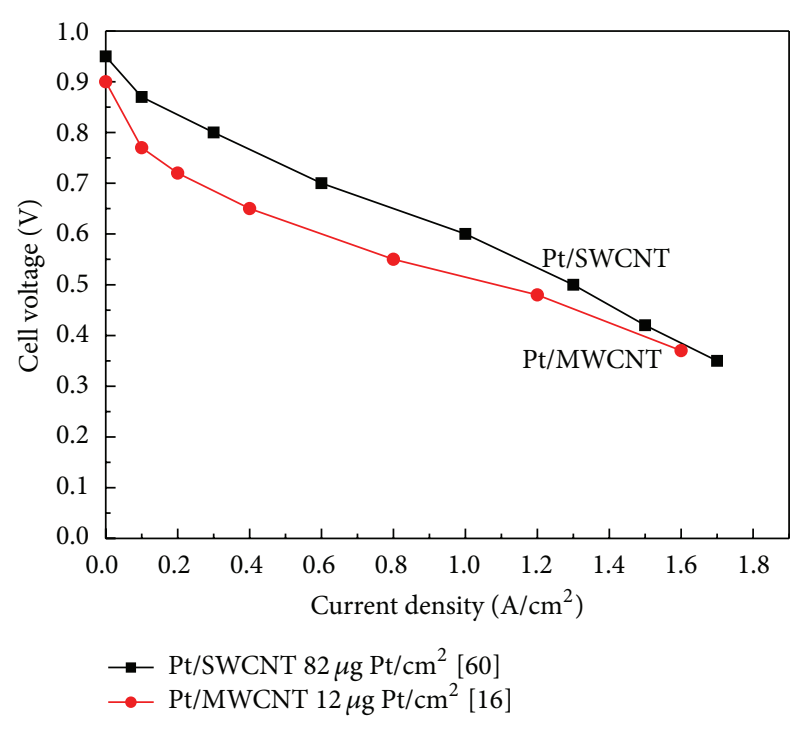

FIGURE 7: $I$ - $V$ characteristics of fuel cell with cathode.

on the polymer Nafion membrane adding some surfactant and working with functional multiwalled CNTs, makes CNTs have good dispersion. This nanocomposite is measured though thermogravimetric analysis (TGA), and results show that it lowers absorption of methanol and improves thermal stability [91].

\section{Interaction between Catalyst and CNT Support}

5.1. The Catalyst Particles Are More Dispersed with CNT Support. For example, CNT, used as a catalyst to support PtPd, can make PtPd nanoparticles distribute uniformly. CNT directly used in methanol fuel cell increases the activity of the electrochemical surface area and mass activity [92]. Therefore, it is important for carbon nanostructure as the support material and it can effectively disperse catalyst particles [93].

5.2. CNT Diameter and Number of Layers. When CNTsupported $\mathrm{Pt}$ nanoparticles are used for ORR, the specific surface area decreases with the diameter of the CNT increasing. When the diameter of CNT increases, the performance of Pt catalyst becomes more stable and the amount of $\mathrm{Pt}$ loading reduces [94]. Besides, multiwalled CNTs have better performance than single-walled CNTs [95]. As shown in Figure 7, the curves are the comparing cathode catalyst made of $82 \mu \mathrm{g} \mathrm{Pt} / \mathrm{cm}^{2} \mathrm{Pt} / \mathrm{SWCNT}$ and $12 \mu \mathrm{g} \mathrm{Pt} / \mathrm{cm}^{2} \mathrm{Pt} / \mathrm{MWCNT}$, while other conditions do not have too much discrepancy. Even through Pt/SWCNT has a higher Pt loading, their cell voltages do not generate the great difference.

5.3. Adhesion between the Pt Nanoparticles and Support. He et al. studied how the size and the shape of Pt nanoparticles affect the catalytic performance. The results show that as the size of the Pt nanoparticles is larger, adhesive force becomes bigger regardless of the humidity. When the nanoparticles are tetrahedral, it has good adhesion. But other shapes did not significantly impact the adhesion. When the humidity of Nafion membrane is increased, enhanced hydration leads to weakened adhesion. At the same time, controlling the content of the Nafion membrane can also improve the absorption [96].

\section{The Synthetic Conditions of CNTs Catalyst}

6.1. In Supercritical Fluid. If platinum CNTs are synthesized in supercritical fluids, they can be electrocatalyst for the low temperature fuel cells [97] or for the direct methanol fuel cell [98].

6.2. The Application of Microwave Technology. The CNTs can be manufactured though microwave-assisted reduction polyol method, and then platinum deposits on the CNTs to form the catalyst. The catalyst can be used in direct methanol fuel cells [99]. Chloroplatinic acid is used in providing Pt to synthesize platinum catalyst by the intermittent microwave radiation technology. This platinum catalyst has better performance than commercial platinum carbon black catalyst [100]. The vertically oriented CNT is synthesized using a microwave plasma enhanced chemical vapor deposition method. Then platinum nanoparticles are deposited on the CNT by DC sputtering system to form the catalyst. Increasing surface nitrogen content of this catalyst is expected to become the future fuel cell electrodes [101].

6.3. Processing in Acid. After CNTs are processed in acid, they can be used to manufacture the catalyst with platinum nanoparticles by chemical deposition method [102].

6.4. Low-Temperature Plasma Method. This method is widely used in the synthesis of CNTs and graphene material applied to the fuel cell, because it is possible to obtain many advantages like highly dispersed active substances, reducing energy requirements, enhancing the activation of the catalyst, shortening the synthetic time, reducing environmental pollution, and so on [103].

\section{Summary and Outlook}

Fuel cells have the nature of high energy conversion efficiency and low pollutant emission and are considered to be one of the promising methods to solve future energy crisis and environmental issues. Carbon nanotube used as the support of catalysis has an important significance in the fuel cell applications. We summarize and discuss the application of carbon nanotubes in fuel cells. We focus on the effect of carbon nanotubes on the fuel cell in which the ways are used to reduce the need of noble metal and to improve the performance of fuel cell catalysts, as well as the interaction with catalyst and carbon nanotube support and the synthesis conditions of carbon nanotube supported catalyst.

Researches about the support of CNTs and catalyst's performance have made a lot of achievements and make us much more clearly to understand the effects of the CNT 
on fuel cell. However, the microscopic transport mechanism in CNTs remains to be further studied. The molecular dynamics simulation should be a powerful method to study the microscopic transmission in CNTs.

\section{Conflict of Interests}

The authors declare that there is no conflict of interests regarding the publication of this paper.

\section{Acknowledgments}

This work is supported by the Natural Science Foundation of Chongqing (Grant no. cstc2013jcyjA90009), the National Natural Science Foundation of China (Grant no. 51206195), and the Fundamental Research Funds for the Central Universities of Ministry of Education of China (Grant no. CDJZR12110033).

\section{References}

[1] A. S. Aricò, S. Srinivasan, and V. Antonucci, "DMFCs: from fundamental aspects to technology development," Fuel Cells, vol. 1, no. 2, pp. 133-161, 2001.

[2] F. T. Wagner, B. Lakshmanan, and M. F. Mathias, "Electrochemistry and the future of the automobile," Journal of Physical Chemistry Letters, vol. 1, no. 14, pp. 2204-2219, 2010.

[3] M. K. Debe, "Electrocatalyst approaches and challenges for automotive fuel cells," Nature, vol. 486, no. 7401, pp. 43-51, 2012.

[4] M. K. Debe, A. K. Schmoeckel, G. D. Vernstrom, and R. Atanasoski, "High voltage stability of nanostructured thin film catalysts for PEM fuel cells," Journal of Power Sources, vol. 161, no. 2, pp. 1002-1011, 2006.

[5] K. Wan, G. Long, M. Liu, L. Du, Z. Liang, and P. Tsiakaras, "Nitrogen-doped ordered mesoporous carbon: synthesis and active sites for electrocatalysis of oxygen reduction reaction," Applied Catalysis B: Environmental, vol. 165, pp. 566-571, 2015.

[6] L. Zhao, Z. Wang, J. Li, J. Zhang, X. Sui, and L. Zhang, "A newly-designed sandwich-structured graphene-Pt-graphene catalyst with improved electrocatalytic performance for fuel cells," Journal of Materials Chemistry A, vol. 3, no. 10, pp. 53135320, 2015.

[7] J.-H. Wee, K.-Y. Lee, and S. H. Kim, "Fabrication methods for low-Pt-loading electrocatalysts in proton exchange membrane fuel cell systems," Journal of Power Sources, vol. 165, no. 2, pp. 667-677, 2007.

[8] E. Negro, R. Latsuzbaia, M. Dieci, I. Boshuizen, and G. J. Koper, "Pt electrodeposited over carbon nano-networks grown on carbon paper as durable catalyst for PEM fuel cells," Applied Catalysis B: Environmental, vol. 166-167, pp. 155-165, 2015.

[9] J.-Y. Choi, D. Higgins, and Z. Chen, "Highly durable graphene nanosheet supported iron catalyst for oxygen reduction reaction in PEM fuel cells," Journal of the Electrochemical Society, vol. 159, no. 1, pp. B86-B89, 2012.

[10] N. Rajalakshmi, H. Ryu, M. M. Shaijumon, and S. Ramaprabhu, "Performance of polymer electrolyte membrane fuel cells with carbon nanotubes as oxygen reduction catalyst support material," Journal of Power Sources, vol. 140, no. 2, pp. 250-257, 2005.

[11] N. Jha, P. Ramesh, E. Bekyarova et al., "Functionalized singlewalled carbon nanotube-based fuel cell benchmarked against
US DOE 2017 technical targets," Scientific Reports, vol. 3, article 2257, 2013.

[12] G. Girishkumar, M. Rettker, R. Underhile et al., "Single-wall carbon nanotube-based proton exchange membrane assembly for hydrogen fuel cells," Langmuir, vol. 21, no. 18, pp. 8487-8494, 2005.

[13] T. Matsumoto, T. Komatsu, K. Arai et al., "Reduction of Pt usage in fuel cell electrocatalysts with carbon nanotube electrodes," Chemical Communications, vol. 10, no. 7, pp. 840-841, 2004.

[14] X. Sun, R. Li, D. Villers, J. P. Dodelet, and S. Désilets, "Composite electrodes made of Pt nanoparticles deposited on carbon nanotubes grown on fuel cell backings," Chemical Physics Letters, vol. 379, no. 1-2, pp. 99-104, 2003.

[15] H. Liu, C. Song, L. Zhang, J. Zhang, H. Wang, and D. P. Wilkinson, "A review of anode catalysis in the direct methanol fuel cell," Journal of Power Sources, vol. 155, no. 2, pp. 95-110, 2006.

[16] J. M. Tang, K. Jensen, M. Waje et al., "High performance hydrogen fuel cells with ultralow Pt loading carbon nanotube thin film catalysts," The Journal of Physical Chemistry C, vol. 111, no. 48, pp. 17901-17904, 2007.

[17] N. Jha, A. Leela Mohana Reddy, M. M. Shaijumon, N. Rajalakshmi, and S. Ramaprabhu, "Pt-Ru/multi-walled carbon nanotubes as electrocatalysts for direct methanol fuel cell," International Journal of Hydrogen Energy, vol. 33, no. 1, pp. 427-433, 2008.

[18] L. Li and Y. C. Xing, "Pt-Ru nanoparticles supported on carbon nanotubes as methanol fuel cell catalysts," Journal of Physical Chemistry C, vol. 111, no. 6, pp. 2803-2808, 2007.

[19] H. Wang, X. Wang, J. Zheng, F. Peng, and H. Yu, "Enhanced activity and durability of nanosized $\mathrm{Pt}-\mathrm{SnO}_{2} / \mathrm{IrO}_{2} / \mathrm{CNTs}$ catalyst for methanol electrooxidation," Journal of Nanoscience and Nanotechnology, vol. 15, no. 5, pp. 3662-3669, 2015.

[20] Y. Zhao, L. Fan, J. Ren, and B. Hong, "Electrodeposition of Pt$\mathrm{Ru}$ and $\mathrm{Pt}-\mathrm{Ru}-\mathrm{Ni}$ nanoclusters on multi-walled carbon nanotubes for direct methanol fuel cell," International Journal of Hydrogen Energy, vol. 39, no. 9, pp. 4544-4557, 2014.

[21] S. Saipanya, S. Lapanantnoppakhun, and T. Sarakonsri, "Electrochemical deposition of platinum and palladium on gold nanoparticles loaded carbon nanotube support for oxidation reactions in fuel cell," Journal of Chemistry, vol. 2014, Article ID 104514, 6 pages, 2014.

[22] J. Wu, J. Zhang, Z. Peng, S. Yang, F. T. Wagner, and H. Yang, "Truncated octahedral Pt3Ni oxygen reduction reaction electrocatalysts," Journal of the American Chemical Society, vol. 132, no. 14, pp. 4984-4985, 2010.

[23] V. R. Stamenkovic, B. Fowler, B. S. Mun et al., "Improved oxygen reduction activity on $\mathrm{Pt} 3 \mathrm{Ni}(111)$ via increased surface site availability," Science, vol. 315, no. 5811, pp. 493-497, 2007.

[24] V. R. Stamenkovic, B. S. Mun, M. Arenz et al., "Trends in electrocatalysis on extended and nanoscale Pt-bimetallic alloy surfaces," Nature Materials, vol. 6, no. 3, pp. 241-247, 2007.

[25] B. Lim, M. Jiang, P. H. C. Camargo et al., "Pd-Pt bimetallic nanodendrites with high activity for oxygen reduction," Science, vol. 324, no. 5932, pp. 1302-1305, 2009.

[26] K. D. Beard, D. Borrelli, A. M. Cramer, D. Blom, J. W. Van Zee, and J. R. Monnier, "Preparation and structural analysis of carbon-supported co core/pt shell electrocatalysts using electroless deposition methods," ACS Nano, vol. 3, no. 9, pp. 2841-2853, 2009. 
[27] C. Wang, H. Daimon, and S. Sun, "Dumbbell-like Pt-Fe $\mathrm{O}_{4}$ nanoparticles and their enhanced catalysis for oxygen reduction reaction," Nano Letters, vol. 9, no. 4, pp. 1493-1496, 2009.

[28] K.-T. Jeng, C.-C. Chien, N.-Y. Hsu et al., "Performance of direct methanol fuel cell using carbon nanotube-supported Pt-Ru anode catalyst with controlled composition," Journal of Power Sources, vol. 160, no. 1, pp. 97-104, 2006.

[29] N.-Y. Hsu, C.-C. Chien, and K.-T. Jeng, "Characterization and enhancement of carbon nanotube-supported PtRu electrocatalyst for direct methanol fuel cell applications," Applied Catalysis B: Environmental, vol. 84, no. 1-2, pp. 196-203, 2008.

[30] J. Prabhuram, T. S. Zhao, Z. K. Tang, R. Chen, and Z. X. Liang, "Multiwalled carbon nanotube supported PtRu for the anode of direct methanol fuel cells," The Journal of Physical Chemistry B, vol. 110, no. 11, pp. 5245-5252, 2006.

[31] B. N. Wanjala, R. Loukrakpam, J. Luo et al., "Thermal treatment of PtNiCo electrocatalysts: effects of nanoscale strain and structure on the activity and stability for the oxygen reduction reaction," The Journal of Physical Chemistry C, vol. 114, no. 41, pp. 17580-17590, 2010.

[32] X. Sheng, B. Wouters, T. Breugelmans, A. Hubin, I. F. J. Vankelecom, and P. P. Pescarmona, " $\mathrm{Cu} / \mathrm{CuxO}$ and Pt nanoparticles supported on multi-walled carbon nanotubes as electrocatalysts for the reduction of nitrobenzene," Applied Catalysis B: Environmental, vol. 147, pp. 330-339, 2014.

[33] S. Wang, D. Yu, and L. Dai, "Polyelectrolyte functionalized carbon nanotubes as efficient metal-free electrocatalysts for oxygen reduction," Journal of the American Chemical Society, vol. 133, no. 14, pp. 5182-5185, 2011.

[34] A. L. Mohana Reddy, N. Rajalakshmi, and S. Ramaprabhu, "Cobalt-polypyrrole-multiwalled carbon nanotube catalysts for hydrogen and alcohol fuel cells," Carbon, vol. 46, no. 1, pp. 2-11, 2008.

[35] T. Matsumoto, Y. Nagashima, T. Yamazaki, and J. Nakamura, "Fuel cell anode composed of Mo2C catalyst and carbon nanotube electrodes," Electrochemical and Solid-State Letters, vol. 9, no. 3, pp. A160-A162, 2006.

[36] A. Mehdinia, E. Ziaei, and A. Jabbari, "Multi-walled carbon nanotube/ $\mathrm{SnO}_{2}$ nanocomposite: a novel anode material for microbial fuel cells," Electrochimica Acta, vol. 130, pp. 512-518, 2014.

[37] Y. Wang, B. Li, D. Cui, X. Xiang, and W. Li, "Nano-molybdenum carbide/carbon nanotubes composite as bifunctional anode catalyst for high-performance Escherichia coli-based microbial fuel cell," Biosensors \& Bioelectronics, vol. 51, pp. 349-355, 2014.

[38] H. Gharibi, F. Golmohammadi, and M. Kheirmand, "Palladium/cobalt coated on multi-walled carbon nanotubes as an electro-catalyst for oxygen reduction reaction in passive direct methanol fuel cells," Fuel Cells, vol. 13, no. 6, pp. 987-1004, 2013.

[39] M. Lefèvre, E. Proietti, F. Jaouen, and J. P. Dodelet, "Iron-Based catalysts with improved oxygen reduction activity in polymer electrolyte fuel cells," Science, vol. 324, no. 5923, pp. 71-74, 2009.

[40] K. Gong, F. Du, Z. Xia, M. Durstock, and L. Dai, "Nitrogendoped carbon nanotube arrays with high electrocatalytic activity for oxygen reduction," Science, vol. 323, no. 5915, pp. 760$764,2009$.

[41] J. Zhao, Z. Liu, H. Li et al., "Development of a highly active electrocatalyst via ultrafine $\mathrm{Pd}$ nanoparticles dispersed on pristine graphene," Langmuir, vol. 31, no. 8, pp. 2576-2583, 2015.

[42] C. Venkateswara Rao and Y. Ishikawa, "Activity, selectivity, and anion-exchange membrane fuel cell performance of virtually metal-free nitrogen-doped carbon nanotube electrodes for oxygen reduction reaction," The Journal of Physical Chemistry C, vol. 116, no. 6, pp. 4340-4346, 2012.

[43] A.-C. Johansson, R. B. Yang, K. B. Haugshøj, J. V. Larsen, L. H. Christensen, and E. V. Thomsen, "Ru-decorated Pt nanoparticles on N-doped multi-walled carbon nanotubes by atomic layer deposition for direct methanol fuel cells," International Journal of Hydrogen Energy, vol. 38, no. 26, pp. 11406-11414, 2013.

[44] Y. Mu, H. Liang, J. Hu, L. Jiang, and L. Wan, "Controllable Pt nanoparticle deposition on carbon nanotubes as an anode catalyst for direct methanol fuel cells," The Journal of Physical Chemistry B, vol. 109, no. 47, pp. 22212-22216, 2005.

[45] S. Ghosh and C. R. Raj, "Facile in situ synthesis of multiwall carbon nanotube supported flowerlike pt nanostructures: an efficient electrocatalyst for fuel cell application," The Journal of Physical Chemistry C, vol. 114, no. 24, pp. 10843-10849, 2010.

[46] S. Y. Wang, S. P. Jiang, T. J. White, J. Guo, and X. Wang, "Electrocatalytic activity and interconnectivity of Pt nanoparticles on multiwalled carbon nanotubes for fuel cells," Journal of Physical Chemistry C, vol. 113, no. 43, pp. 18935-18945, 2009.

[47] T. S. Miller, S. Sansuk, S. Pei E, S. C. Lai, J. V. Macpherson, and P. R. Unwin, "Pt nanoparticle modified single walled carbon nanotube network electrodes for electrocatalysis: control of the specific surface area over three orders of magnitude," Catalysis Today, vol. 244, pp. 136-145, 2015.

[48] M. Borghei, G. Scotti, P. Kanninen et al., "Enhanced performance of a silicon microfabricated direct methanol fuel cell with PtRu catalysts supported on few-walled carbon nanotubes," Energy, vol. 65, pp. 612-620, 2014.

[49] K. Lee, J. Zhang, H. Wang, and D. P. Wilkinson, "Progress in the synthesis of carbon nanotube- and nanofiber-supported Pt electrocatalysts for PEM fuel cell catalysis," Journal of Applied Electrochemistry, vol. 36, no. 5, pp. 507-522, 2006.

[50] F. Hasché, M. Oezaslan, and P. Strasser, "Activity, stability and degradation of multi walled carbon nanotube (MWCNT) supported Pt fuel cell electrocatalysts," Physical Chemistry Chemical Physics, vol. 12, no. 46, pp. 15251-15258, 2010.

[51] Z. Wen, Q. Wang, and J. Li, “Template synthesis of aligned carbon nanotube arrays using glucose as a carbon source: $\mathrm{Pt}$ decoration of inner and outer nanotube surfaces for fuel-cell catalysts," Advanced Functional Materials, vol. 18, no. 6, pp. 959964, 2008.

[52] T. Yoshitake, Y. Shimakawa, S. Kuroshima et al., "Preparation of fine platinum catalyst supported on single-wall carbon nanohorns for fuel cell application," Physica B: Condensed Matter, vol. 323, no. 1-4, pp. 124-126, 2002.

[53] W. Li, X. Wang, Z. Chen, M. Waje, and Y. Yan, "Carbon nanotube film by filtration as cathode catalyst support for protonexchange membrane fuel cell," Langmuir, vol. 21, no. 21, pp. 9386-9389, 2005.

[54] J. E. Mink and M. M. Hussain, "Sustainable design of highperformance microsized microbial fuel cell with carbon nanotube anode and air cathode," ACS Nano, vol. 7, no. 8, pp. 69216927, 2013.

[55] M. A. Deyab, "Corrosion protection of aluminum bipolar plates with polyaniline coating containing carbon nanotubes in acidic medium inside the polymer electrolyte membrane fuel cell," Journal of Power Sources, vol. 268, pp. 50-55, 2014.

[56] W. Li, C. Liang, W. Zhou et al., "Preparation and characterization of multiwalled carbon nanotube-supported platinum for cathode catalysts of direct methanol fuel cells," The Journal of Physical Chemistry B, vol. 107, no. 26, pp. 6292-6299, 2003. 
[57] H. Tang, J. H. Chen, Z. P. Huang et al., "High dispersion and electrocatalytic properties of platinum on well-aligned carbon nanotube arrays," Carbon, vol. 42, no. 1, pp. 191-197, 2004.

[58] W. Zhang, P. Sherrell, A. I. Minett, J. M. Razal, and J. Chen, "Carbon nanotube architectures as catalyst supports for proton exchange membrane fuel cells," Energy \& Environmental Science, vol. 3, no. 9, pp. 1286-1293, 2010.

[59] X. Wang, W. Li, Z. Chen, M. Waje, and Y. Yan, "Durability investigation of carbon nanotube as catalyst support for proton exchange membrane fuel cell," Journal of Power Sources, vol. 158, no. 1, pp. 154-159, 2006.

[60] J. M. Tang, K. Jensen, W. Li et al., "Carbon nanotube freestanding membrane of Pt/SWNTs as catalyst layer in hydrogen fuel cells," Australian Journal of Chemistry, vol. 60, no. 7, pp. 528-532, 2007.

[61] H.-T. Chou, H. Lee, C. Lee, N. Tai, and H. Chang, "Highly durable anodes of microbial fuel cells using a reduced graphene oxide/carbon nanotube-coated scaffold," Bioresource Technology, vol. 169, pp. 532-536, 2014.

[62] T. Matsumoto, T. Komatsu, H. Nakano et al., "Efficient usage of highly dispersed Pt on carbon nanotubes for electrode catalysts of polymer electrolyte fuel cells," Catalysis Today, vol. 90, no. 34, pp. 277-281, 2004.

[63] C. Wang, M. Waje, X. Wang, J. M. Tang, R. C. Haddon, and Y. Yan, "Proton exchange membrane fuel cells with carbon nanotube based electrodes," Nano Letters, vol. 4, no. 2, pp. 345-348, 2004.

[64] G. Girishkumar, K. Vinodgopal, and P. V. Kamat, "Carbon nanostructures in portable fuel cells: single-walled carbon nanotube electrodes for methanol oxidation and oxygen reduction," The Journal of Physical Chemistry B, vol. 108, no. 52, pp. 1996019966, 2004.

[65] Á. Varga, M. Pfohl, N. A. Brunelli, M. Schreier, K. P. Giapis, and S. M. Haile, "Carbon nanotubes as electronic interconnects in solid acid fuel cell electrodes," Physical Chemistry Chemical Physics, vol. 15, no. 37, pp. 15470-15476, 2013.

[66] J. E. Mink, J. P. Rojas, B. E. Logan, and M. M. Hussain, "Vertically grown multiwalled carbon nanotube anode and nickel silicide integrated high performance microsized $(1.25 \mu \mathrm{l})$ microbial fuel cell," Nano Letters, vol. 12, no. 2, pp. 791-795, 2012.

[67] P. Ramesh, M. E. Itkis, J. M. Tang, and R. C. Haddon, "SWNTMWNT hybrid architecture for proton exchange membrane fuel cell cathodes," The Journal of Physical Chemistry C, vol. 112, no. 24, pp. 9089-9094, 2008.

[68] Y. Zhou, K. Neyerlin, T. S. Olson et al., "Enhancement of Pt and Pt-alloy fuel cell catalyst activity and durability via nitrogenmodified carbon supports," Energy \& Environmental Science, vol. 3, no. 10, pp. 1437-1446, 2010.

[69] T. Maiyalagan, B. Viswanathan, and U. V. Varadaraju, "Nitrogen containing carbon nanotubes as supports for Pt-alternate anodes for fuel cell applications," Electrochemistry Communications, vol. 7, no. 9, pp. 905-912, 2005.

[70] Z. Chen, D. Higgins, H. Tao, and R. S. Hsu, "Highly active nitrogen-doped carbon nanotubes for oxygen reduction reaction in fuel cell applications," The Journal of Physical Chemistry C, vol. 113, no. 49, pp. 21008-21013, 2009.

[71] Y. Cheng, C. Xu, P. K. Shen, and S. P. Jiang, "Effect of nitrogencontaining functionalization on the electrocatalytic activity of PtRu nanoparticles supported on carbon nanotubes for direct methanol fuel cells," Applied Catalysis B: Environmental, vol. 158-159, pp. 140-149, 2014.
[72] P. Kanninen, M. Borghei, O. Sorsa et al., "Highly efficient cathode catalyst layer based on nitrogen-doped carbon nanotubes for the alkaline direct methanol fuel cell," Applied Catalysis B: Environmental, vol. 156-157, pp. 341-349, 2014.

[73] N. Jha, R. I. Jafri, N. Rajalakshmi, and S. Ramaprabhu, "Graphene-multi walled carbon nanotube hybrid electrocatalyst support material for direct methanol fuel cell," International Journal of Hydrogen Energy, vol. 36, no. 12, pp. 7284-7290, 2011.

[74] K. Pham, D. H. Chua, D. S. McPhail, and A. T. Wee, "The direct growth of graphene-carbon nanotube hybrids as catalyst support for high-performance PEM fuel cells," ECS Electrochemistry Letters, vol. 3, no. 6, pp. F37-F40, 2014.

[75] H. G. Li, X. Zhang, D. He, T. Peng, and S. Mu, "Carbon-embedded carbon nanotubes as supports of polymer electrolyte membrane fuel cell catalysts," Journal of Nanoscience and Nanotechnology, vol. 14, no. 9, pp. 6929-6933, 2014.

[76] M. Sahoo, B. P. Vinayan, and S. Ramaprabhu, "Platinum-decorated chemically modified reduced graphene oxide-multiwalled carbon nanotube sandwich composite as cathode catalyst for a proton exchange membrane fuel cell," RSC Advances, vol. 4, no. 50, pp. 26140-26148, 2014.

[77] A. Kausar, A. Hussain, M. Y. Khan, and M. Siddiq, "Fuel cell membranes prepared from multi-walled carbon nanotubes and silica nanotubes-filled sulfonated polyamide/sulfonated polystyrene porous blend films," Journal of Plastic Film \& Sheeting, vol. 30, no. 3, pp. 314-336, 2014.

[78] Y. J. Sa, C. Park, H. Y. Jeong et al., "Carbon nanotubes/heteroatom-doped carbon core-sheath nanostructures as highly active, metal-free oxygen reduction electrocatalysts for alkaline fuel cells," Angewandte Chemie International Edition, vol. 53, no. 16, pp. 4102-4106, 2014.

[79] Y. Show and K. Takahashi, "Stainless steel bipolar plate coated with carbon nanotube (CNT)/polytetrafluoroethylene (PTFE) composite film for proton exchange membrane fuel cell (PEMFC)," Journal of Power Sources, vol. 190, no. 2, pp. 322-325, 2009.

[80] T.-H. Nguyen, Y.-Y. Yu, X. Wang, J.-Y. Wang, and H. Song, "A 3D mesoporous polysulfone-carbon nanotube anode for enhanced bioelectricity output in microbial fuel cells," Chemical Communications, vol. 49, no. 91, pp. 10754-10756, 2013.

[81] A. Sayeed, Y. H. Kim, Y. Park, A. I. Gopalan, K.-P. Lee, and S.-J. Choi, "Non-covalent bonding interaction of surfactants with functionalized carbon nanotubes in proton exchange membranes for fuel cell applications," Journal of Nanoscience and Nanotechnology, vol. 13, no. 11, pp. 7424-7429, 2013.

[82] T. H. Oh, B. Jang, and S. Kwon, "Electrocatalysts supported on multiwalled carbon nanotubes for direct borohydride-hydrogen peroxide fuel cell," International Journal of Hydrogen Energy, vol. 39, no. 13, pp. 6977-6986, 2014.

[83] W. M. Daoush and T. Imae, "Fabrication of PtNi bimetallic nanoparticles supported on multi-walled carbon nanotubes," Journal of Experimental Nanoscience, vol. 10, no. 5, pp. 392-406, 2015.

[84] A. M. Valenzuela-Muñiz, G. Alonso-Nuñez, G. G. Botte, M. Miki-Yoshida, and Y. Verde-Gómez, "Influence of nickel on the electrochemical activity of PtRu/multiwalled carbon nanotubes electrocatalysts for direct methanol fuel cells," Journal of Applied Electrochemistry, vol. 44, no. 6, pp. 695-700, 2014.

[85] L. Samiee, F. Shoghi, and A. Maghsodi, "In situ functionalisation of mesoporous carbon electrodes with carbon nanotubes for proton exchange membrane fuel-cell application," Materials Chemistry and Physics, vol. 143, no. 3, pp. 1228-1235, 2014. 
[86] J. B. Liu, Y. Yuan, and S. Bashir, "Functionalization of aligned carbon nanotubes to enhance the performance of fuel cell," Energies, vol. 6, no. 12, pp. 6476-6486, 2013.

[87] S. Murata, M. Imanishi, S. Hasegawa, and R. Namba, "Vertically aligned carbon nanotube electrodes for high current density operating proton exchange membrane fuel cells," Journal of Power Sources, vol. 253, pp. 104-113, 2014.

[88] N. Thepsuparungsikul, T. C. Ng, O. Lefebvre, and H. Y. Ng, "Different types of carbon nanotube-based anodes to improve microbial fuel cell performance," Water Science and Technology, vol. 69, no. 9, pp. 1900-1910, 2014.

[89] Y. Cheng-Bing, X. Hui, and L. Chao, "Molecular dynamics simulation of average velocity of lithium iron across the end of carbon nanotube," Acta Physica Sinica, vol. 63, no. 20, Article ID 200508, 2014.

[90] M. Wu and L. L. Shaw, "A novel concept of carbon-filled polymer blends for applications in PEM fuel cell bipolar plates," International Journal of Hydrogen Energy, vol. 30, no. 4, pp. 373380, 2005.

[91] Y. H. Kim, A. Sayeed, Y. Park, A. I. Gopalan, K.-P. Lee, and S.-J. Choi, "Functionalized carbon nanotubes reinforced polymer electrolyte membranes prepared by surfactant-assisted casting for fuel cell applications," Journal of Nanoelectronics and Optoelectronics, vol. 8, no. 6, pp. 551-556, 2013.

[92] H. L. Wang, B. A. Kakade, T. Tamaki, and T. Yamaguchi, "Synthesis of 3D graphite oxide-exfoliated carbon nanotube carbon composite and its application as catalyst support for fuel cells," Journal of Power Sources, vol. 260, pp. 338-348, 2014.

[93] G. Girishkumar, T. D. Hall, K. Vinodgopal, and P. V. Kamat, "Single wall carbon nanotube supports for portable direct methanol fuel cells," Journal of Physical Chemistry B, vol. 110, no. 1, pp. 107-114, 2006.

[94] A. O. Al-Youbi, J. L. Gómez de la Fuente, F. J. Pérez-Alonso et al., "Effects of multiwalled carbon nanotube morphology on the synthesis and electrocatalytic performance of Pt supported by multiwalled carbon nanotubes," Applied Catalysis B: Environmental, vol. 150-151, pp. 21-29, 2014.

[95] M. Carmo, V. A. Paganin, J. M. Rosolen, and E. R. Gonzalez, "Alternative supports for the preparation of catalysts for lowtemperature fuel cells: the use of carbon nanotubes," Journal of Power Sources, vol. 142, no. 1-2, pp. 169-176, 2005.

[96] Q. He, D. C. Joy, and D. J. Keffer, "Nanoparticle adhesion in proton exchange membrane fuel cell electrodes," Journal of Power Sources, vol. 241, pp. 634-646, 2013.

[97] Y. Lin, X. Cui, C. Yen, and C. M. Wai, "Platinum/carbon nanotube nanocomposite synthesized in supercritical fluid as electrocatalysts for low-temperature fuel cells," The Journal of Physical Chemistry B, vol. 109, no. 30, pp. 14410-14415, 2005.

[98] Y. Lin, X. Cui, C. H. Yen, and C. M. Wai, "PtRu/carbon nanotube nanocomposite synthesized in supercritical fluid: a novel electrocatalyst for direct methanol fuel cells," Langmuir, vol. 21, no. 24, pp. 11474-11479, 2005.

[99] M. Sakthivel, A. Schlange, U. Kunz, and T. Turek, "Microwave assisted synthesis of surfactant stabilized platinum/carbon nanotube electrocatalysts for direct methanol fuel cell applications," Journal of Power Sources, vol. 195, no. 20, pp. 7083-7089, 2010.

[100] Z. Q. Tian, S. P. Jiang, Y. M. Liang, and P. K. Shen, "Synthesis and characterization of platinum catalysts on multiwalled carbon nanotubes by intermittent microwave irradiation for fuel cell applications," Journal of Physical Chemistry B, vol. 110, no. 11, pp. 5343-5350, 2006.
[101] N. Soin, S. S. Roy, L. Karlsson, and J. A. McLaughlin, "Sputter deposition of highly dispersed platinum nanoparticles on carbon nanotube arrays for fuel cell electrode material," Diamond and Related Materials, vol. 19, no. 5-6, pp. 595-598, 2010.

[102] Z. Liu, X. Lin, J. Y. Lee, W. Zhang, M. Han, and L. M. Gan, "Preparation and characterization of platinum-based electrocatalysts on multiwalled carbon nanotubes for proton exchange membrane fuel cells," Langmuir, vol. 18, no. 10, pp. 4054-4060, 2002.

[103] Q. Wang, X. Wang, Z. Chai, and W. Hu, "Low-temperature plasma synthesis of carbon nanotubes and graphene based materials and their fuel cell applications," Chemical Society Reviews, vol. 42, no. 23, pp. 8821-8834, 2013. 

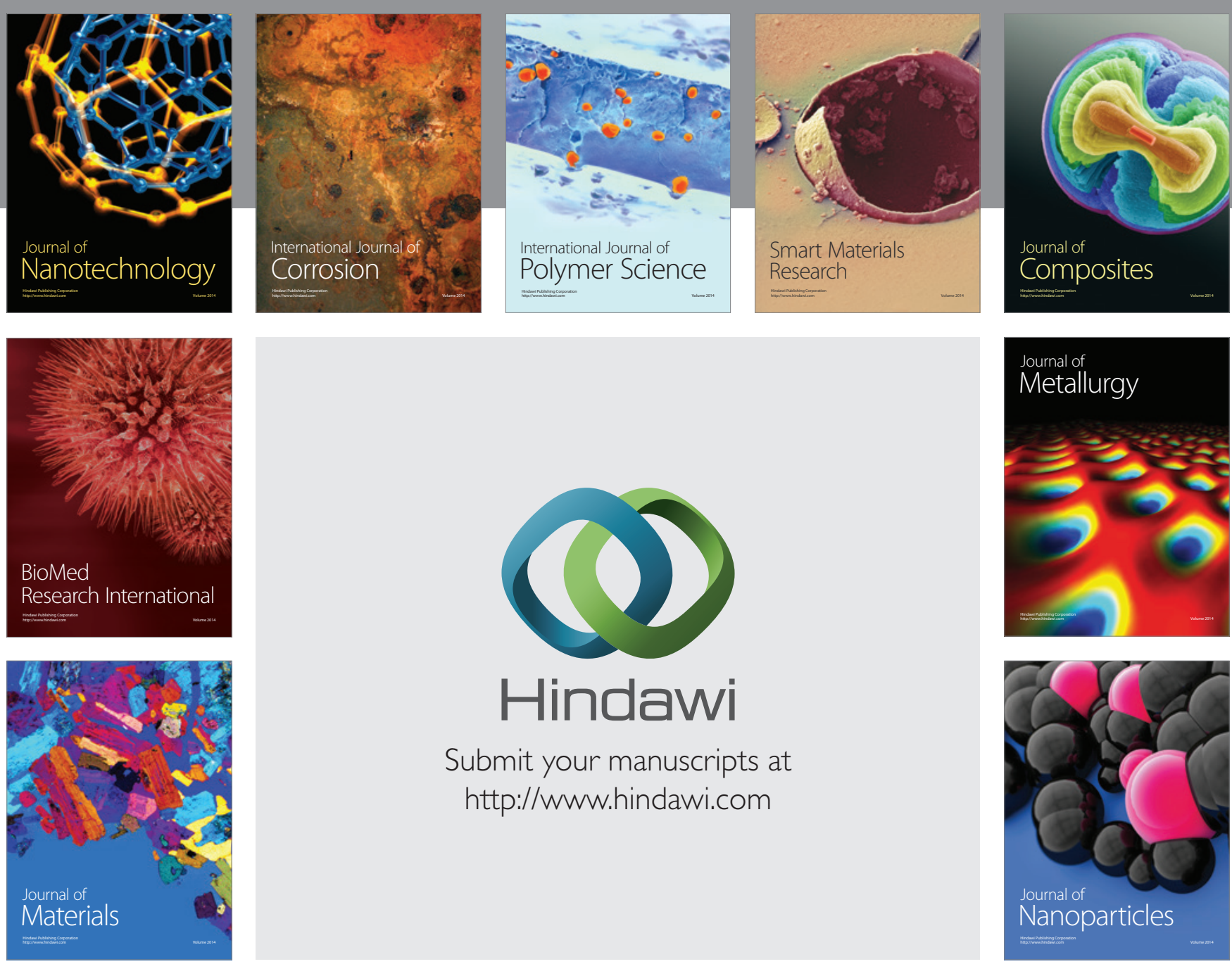

Submit your manuscripts at http://www.hindawi.com
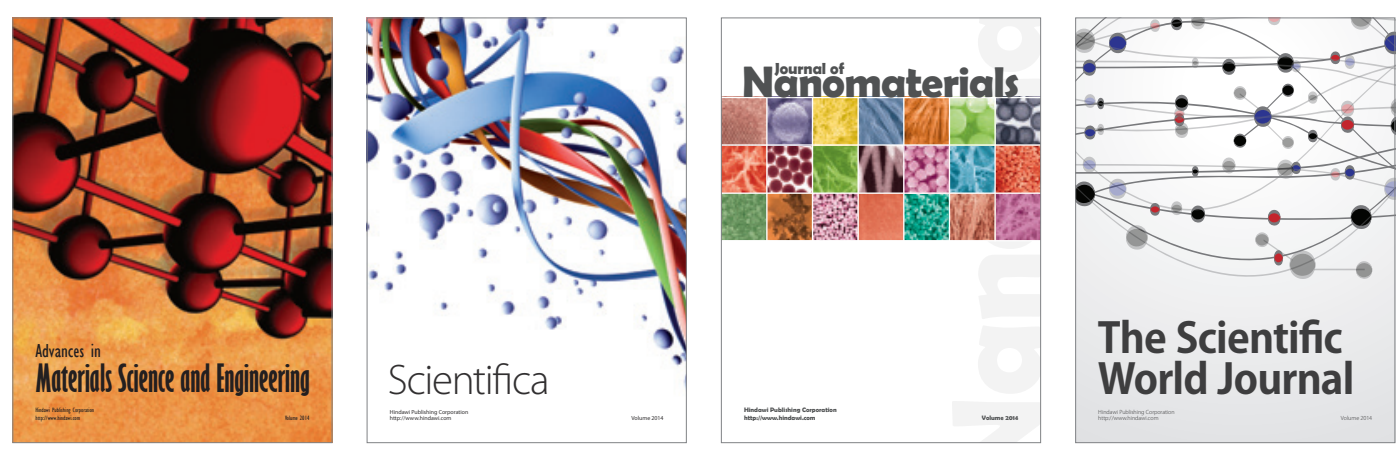

\section{The Scientific World Journal}
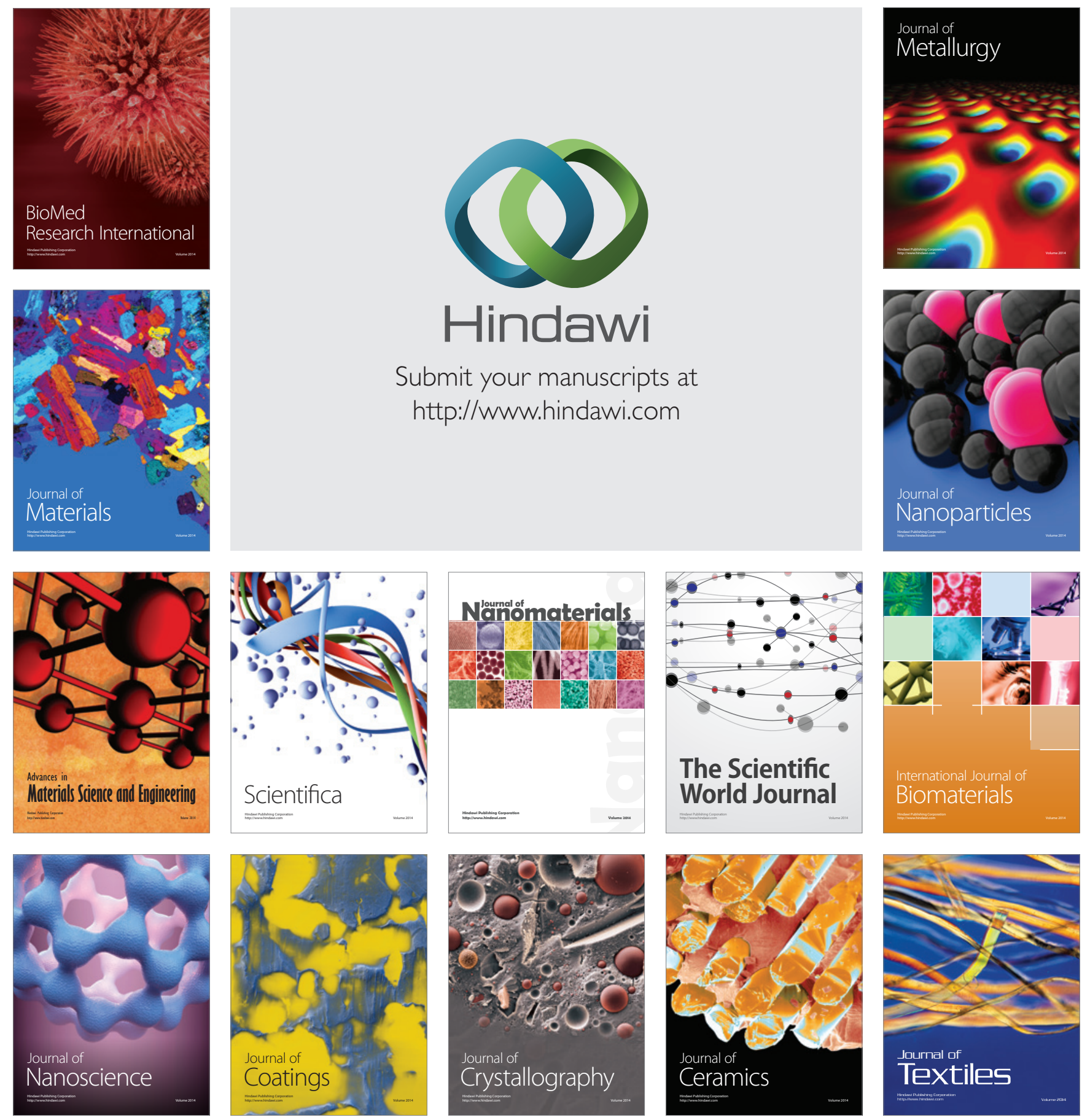